\title{
The Importance of Experiential Learning for Development of Essential Skills in Cross-Cultural and Intercultural Effectiveness
}

Mary Lynch

Follow this and additional works at: https://digitalcommons.tourolaw.edu/jel

Part of the Legal Education Commons

\section{Recommended Citation}

Lynch, Mary (2015) "The Importance of Experiential Learning for Development of Essential Skills in CrossCultural and Intercultural Effectiveness," Journal of Experiential Learning: Vol. 1: Iss. 1, Article 8.

Available at: https://digitalcommons.tourolaw.edu/jel/vol1/iss1/8

This Article is brought to you for free and open access by Digital Commons @ Touro Law Center. It has been accepted for inclusion in Journal of Experiential Learning by an authorized editor of Digital Commons @ Touro Law Center. For more information, please contact Iross@tourolaw.edu. 
The Importance of Experiential Learning for Development of Essential Skills in Cross-Cultural and Intercultural Effectiveness

Cover Page Footnote

$1-1$

This article is available in Journal of Experiential Learning: https://digitalcommons.tourolaw.edu/jel/vol1/iss1/8 


\title{
THE IMPORTANCE OF EXPERIENTIAL LEARNING FOR DEVELOPMENT OF ESSENTIAL SKILLS IN CROSS-CULTURAL AND INTERCULTURAL EFFECTIVENESS
}

\author{
MARY LYNCH*
}

"In life, we all have a cross to bear and a unique story to tell. We just hope that someone will take the time to listen."

- Greg McVicker, Through the Eyes of a Belfast Child Life. Personal Reflections. Poems.

My sister Eileen's 1987 wedding held in our hometown, the Bronx, involved a moment of intercultural misunderstanding. ${ }^{1}$ From at least the time of my parents' wedding in 1959, up until my sister's in 1987, it was customary among Irish immigrant families in New York City (NYC) to have "the telegrams" read aloud at wedding receptions. These telegrams were sent from overseas family members who could not make the trip to the "Yank" wedding, and were read aloud by members of the wedding party to the bride, groom, and guests. At Eileen's wedding, the moment came when the telegrams were read aloud. The first telegram was sweet and thoughtful. Non-Irish guests commented on the loveliness of the custom. The next telegram wished all present at the wedding "good crack." There was a stunned silence in the previously merry room. Since crack cocaine in NYC in the 1980s was a scourge destroying neighborhoods and families, and was certainly not something to make jokes about at a wedding, this telegram appeared to be in very poor taste-its reading creating an awfully awkward moment. Those of us who were first generation Irish rushed to explain to the American guests that "crack/craic"2 is Gaelic

* Mary Lynch is Professor and Director of the Center for Excellence in Law Teaching and Director of the Domestic Violence Prosecution Hybrid Clinic at Albany Law School.

1 For a "satirized" or "realistic" version of Bronx weddings, depending on your viewpoint, see Janet Maslin, Review/Film; 'True Love,' as It Is in the Italian Bronx, N.Y. Times, Oct. 20, 1989, http://www.nytimes.com/1989/10/20/movies/review-film-true-love-asit-is-in-the-italian-bronx.html; Olivia Damavandi, The Bronx on the big-and-small-screen, The Bronx INK, Mar. 1, 2011, http://bronxink.org/2011/03/01/13155-the-bronx-on-the-bigand-small-screen.

2 See Wikipedia for interesting information about the origin of both spellings of the word. Craic, WIKIPEDIA, http://en.wikipedia.org/wiki/Craic (last modified Oct. 10, 2014). 
for fun, entertainment and lively conversation. ${ }^{3}$ Everyone relaxed and there was indeed "mighty craic" that festive night.

The story of my sister's wedding exemplifies a simple and humorous cross-cultural misunderstanding that was quickly corrected and caused no harm. However, cross-cultural miscommunication is not always so benign in consequences. Such miscommunication may interfere with rapport, problem solving and peacemaking. ${ }^{4}$ Cross-cultural misunderstandings may unintentionally offend others and scar relationships. ${ }^{5}$ This is especially true when, as in the lawyer-client relationship, one individual needs to place trust in the advice and judgment of another individual. Beyond lawyer-client interactions, unintentional exercises of cultural privilege or bias by lawyers may lead to unfairness in the creation, regulation, interpretation or implementation of laws, thereby affecting the legitimacy of our legal systems in the eyes of community members. ${ }^{6}$

One typical but recurrent example involving real damage and real legal consequences is the misdiagnosis of a non-majoritarian child's injury by majoritarian health and/or social service workers. One such misdiagnosis occurred in Washington State when an infant was removed to foster care because of misidentification of "blue spots"7 as abuse bruises:

3 Elaine Walsh, The Craic is Mighty, http://www.ireland-fun-facts.com/craic.html (last visited Oct. 19, 2014).

4 See generally Franklin A. Gevartz, Report Regarding the 2011 Pacific McGeorge Workshop on Promoting Intercultural Legal Competence (the "Tahoe II" conference), 26 Pac. McGeorge Global Bus. \& Dev. L.J. 63 (2013); Rachel Moran, When Intercultural Competency Comes to Class: Navigating Difference in the Modern American Law School, 26 Pac. McGeorge Global Bus. \& Dev. L.J. 109 (2013). For the definition of "multicultural education," see Johanna K.P. Dennis, Ensuring a Multicultural Educational Experience in Legal Education: Start With the Legal Writing Classroom, 16 Tex. Wesleyan L. Rev. 613, 614-29 (2010).

5 Avoiding Cross-Cultural Faux Pas: Understanding the Impact of Cross-Cultural Differences, Mind Tools, http://www.mindtools.com/pages/article/cross-cultural-mistakes .htm (last visited Oct. 19, 2014).

6 "To achieve public confidence in a court system, intangible issues, such as litigants' perceptions of judges and juries, must be afforded weighty consideration. At times, a litigant may perceive a disparity or divide between his or her own value system or identity and that of the judge." Melissa L. Breger, Introducing the Construct of the Jury into Family Violence Proceedings and Family Court Jurisprudence, 13 Мich. J. GENDER \& L. 1, 24 (2006).

7 "Caused by simple variations in pigment, Mongolian spots are much more prevalent in babies of color, appearing in more than 90 percent of Native Americans and children of African descent, more than 80 percent of Asians, and more than 70 percent of Hispanics. They are rare in fair-skinned children-appearing in just less than ten percent. . . . No treatment is necessary. Mongolian spots do not predispose people to skin cancer or any other problem, and most often disappear by age two. (Fewer than five percent of children with Mongolian spots still have any by the time they're adults.)" Mongolian Spots, WHAT 
A child-care worker and supervisor misidentified blue spots as bruises on an African-American infant, and when the infant was taken to the hospital, the examining physician also misidentified the blue spots as bruises resulting in the infant being sent to a foster home until the bruises were eventually determined to be blue spots. ${ }^{8}$

Although this example focuses on social service and health care professionals, the blue spots could just as easily have been misinterpreted as abuse bruises by a family court lawyer or prosecutor. Because of the significant consequences that flow from cross-cultural misunderstanding or unawareness in lawyer-client interactions and other lawyer activities, intercultural effectiveness (IE) is a critical student learning outcome for all students attending law school today. ${ }^{9}$

In this essay, I argue two points. First, I posit that the time is ripe for systemizing the development of cross-cultural communication and IE skills ${ }^{10}$ in law students because of the increasingly globalized nature of our world, the American Bar Association (ABA)'s anticipated adoption of a student learning outcomes framework for law schools and the changing landscape for post-law school employment. Cross-cultural skill building will involve some core knowledge development and will require law schools to embrace professional development of values and attitudes that support IE. Second, I believe that law schools can best realize these important student learning out-

TO ЕХРЕст, http://www.whattoexpect.com/first-year/baby-care/baby-skin-care/mongolianspots.aspx (last visited Oct. 19, 2014).

8 William Y. Chin, Blue Spots, Coining, and Cupping: How Ethnic Minority Parents Can Be Misreported As Child Abusers, 7 J. L. Society 88, 114 (2005) (citing Cynthia Flash, Couple Sue Over Child-Abuse Misdiagnosis, Morning News Trib., Tacoma, Wash., Jan. 8, 1993, at B1.).

9 See generally, Lisa Bliss et al., Building on Best Practices: Transforming Legal Education in a Changing World (forthcoming 2015) (discussing how to ready and interest students to pursue intercultural skills through the identification of intercultural learning objectives, teaching of intercultural skill building, and assessing of intercultural effectiveness); William M. Sullivan et al., Educating Lawyers: Preparation for The Profession of Law, The Carnegie Foundation for the Advancement of Teaching (2007) ("The need to understand how cultural experiences affect the legal process is not limited to those engaging in international or cross-border transactions and disputes. Most lawyers will encounter colleagues, judges, jurors, and clients whose cultural perspectives and experiences differ from their own. Failure to understand the role culture plays can limit a lawyer's ability to meet critical legal needs and provide access to justice as well as impede client representation generally.").

10 The evolving language and labels of cross-cultural, intercultural and multicultural have been discussed elsewhere. See, e.g, Andrea A. Curcio, Teresa E. Ward \& Nisha Dogra, A Survey Instrument to Develop, Tailor, and Help Measure Law Student Cultural Diversity Education Learning Outcomes, 38 Nova LAw REviEw 171 (forthcoming 2014), available at: http://papers.ssrn.com/sol3/papers.cfm?abstract_id=2451300. I choose to use both the terms cross-cultural lawyering and intercultural effectiveness in this essay to emphasize the need for knowledge, skills and values important for traditional lawyering as well as for "J.D. advantaged" employment or other entrepreneurial uses of law degrees. 
comes through well-designed, well-supervised, experience-based courses in which law students can more easily overcome their resistance to or defensiveness against learning about cross-cultural issues. Experiential courses, and in particular clinical courses, are best suited for this learning because law students are motivated to improve communication and build relationships when they are responsible for real clients. In addition, because of the repeated real life examples of culture clash which current legal systems and current laws organically provide, clinical courses (including well-supervised field placements) can provide the context for working through the challenges of representing non-majoritarian clients in implicitly biased courts and under particular legal frameworks which privilege the dominant culture. Well-designed clinical and field placement courses also provide structured opportunities for reflecting upon our imperfect and evolving legal systems through intensive, supervised engagement with real legal issues over the course of an entire semester, with opportunities for continuous feedback and assessment by the faculty supervisor. ${ }^{11}$

\section{Legal Education's Failure to Systemize Cross-Cultural AND INTERCULTURAL LEARNING}

Since 2007, three influential reports and studies on legal education have argued for increased attention to the kind of learning opportunities and education prioritization that undergirds IE in law graduates. First, the Clinical Legal Education Association's BEST Practices for Legal Education ${ }^{12}$ specifically described the need to train students about cross-cultural competence, referring readers to the writings of Professor Sue Bryant and Jean Koh Peters on "The Five Habits" for developing competence in cross-cultural lawyering. ${ }^{13}$ The Habits have been cited in "well over 300 law review articles" as well as in amici curiae briefs in "landmark affirmative action litigation." 14 They have also been used to train lawyers and law students

11 Notably, I limit my argument here to a specific set of experiential opportunities because I believe that students need an entire semester's worth of engaged involvement with clients and/or legal systems under directed reflection and supervision in order to work through the complex and nuanced issues specific to effective cross-cultural lawyering, as well as to intercultural skill building and attitude development.

12 Roy Stuckey, et al., Best Practices for Legal Education, Clinical Legal Education Association at 66 (2007).

13 Susan Bryant, The Five Habits: Building Cross-Cultural Competence in Lawyers, 8 Clinical L. Rev. 33 (2001) [hereinafter The Five Habits]; see also Susan Bryant \& Jean Koh Peters, Five Habits for Cross-Cultural Lawyering, in Race, Culture, Psychology \& LAw at 47 (Kimberly Holt Barrett \& William George, eds. 2005) [hereinafter Reflecting on the Habits].

14 Reflecting on the Habits, supra note 13, at p.350 and n.3. 
around the globe, ${ }^{15}$ encouraging practices such as "parallel universe" thinking. ${ }^{16}$ Just recently, Professors Bryant and Peters reflected on the success of this tool, examined lessons they learned from teaching the habits for over fifteen years, and added the tool of "methodological doubt/methodological belief," 17 which develops the ability to alternate between suspending doubt and viewing the world through the eyes, cultural background and experience of the client, and then flipping the lens to view the clients' behavior through the skeptical cultural perspective of the legal decision-maker(s).

Second, also published in 2007, the Carnegie Foundation's EDUCAting Lawyers: Preparation for the Profession of Law ${ }^{18}$ critiqued law schools for not fully integrating the wisdom of engaged practice and professional values into legal education. Although not as direct as Best Practices in identifying sensitivity and effectiveness in cross-cultural relationships as a fundamental value of the profession, Educating Lawyers is known for advocating the kind of skills training and value development in lawyers which directly supports the formation of law graduates who are effective interculturally. For example, in noting exceptional examples of integrated learning during which knowledge, skill, and value development occur simultaneously, the authors point to Professor Sue Bryant's teaching in the CUNY clinics $^{19}$ and Professor Antoinette Sedillo Lopez's teaching at the University of New Mexico clinic. These clinical courses were described as illustrative of teaching "holistic"20 lawyering. Educating Lawyers emphasized that when law students try "to obtain justice" for clients from a diverse set of "cultural backgrounds," not only are students' "practical skills" enhanced but their "understanding of the deep structure of American legal thinking" is enhanced. ${ }^{21}$ Educating Law-

15 For example, see continuing legal education training provided in Illinois and New York. See Susan Bryant and Jean Koh Peters, Five Habits For Cross-Cultural LawyeringSection 1, Illinois Legal Advocate (Oct. 2007), http://www.illinoislegaladvocate.org/ index.cfm?fuseaction=home.dsp_content\&contentID=5986; Susan Bryant, Cultural Competancy 101, Legal Services NYC Learning Center (May 2011), https://www. learningcenter.legalservicesnyc.org/catalog/536; Janet Moore, Effective Cross-cultural Lawyering, InTERnational LAwYer COACH Blog (Jan. 2010), http://www.international lawyercoach.com/blog/2010/01/12/effective-cross-cultural-lawyering/.

16 See discussion of "parallel universe thinking" in The Five Habits Reflecting on the Habits, supra note 13.

17 Reflecting on the Habits, supra note 13, at 364-72.

18 See William M. Sullivan ET AL., supra note 9 (offering recommendations for improving the professional education of lawyers that will help to transform how lawyers are being prepared practically and ethically).

19 Id. at 37.

20 Id. at 121.

21 Id. at 37. 
yers emphasizes, just as Bryant and Koh Peters does, that legal education is itself an acculturation process,

- . . law schools shape the minds and hearts of their graduates in enduring ways. ${ }^{22}$

- For better or worse the law school years constitute a powerful moral apprenticeship, whether or not this is intentional. ${ }^{23}$

- Students are acutely aware of these individualistic values on their campuses. ${ }^{24}$

- Others are disturbed by their fellows' high-handed attitudes toward low-income clients. ${ }^{25}$

Educating Lawyers also recognizes the "kinds of social capacities lawyers need in order to be fully competent, including the capacity to listen carefully, to work collaboratively, and to question their own stereotypes and assumptions (emphasis added)." 26

The third significant report, Professors Marjorie M. Shultz and Sheldon Zedeck's widely known and well-reputed study, Identification, Development, and Validation of Predictors for Successful Lawyering, ${ }^{27}$ identifies 26 factors which are present in successful lawyers, most of which are not tested on the Law School Admissions Test (LSAT). One the "Top 26" effectiveness factors is the ability "to see the World Through the Eyes of Others." 28 This factor or characteristic involves understanding the "positions, views, objectives and goals of others." 29 And as discussed later in this essay, many of the other top factors involve the kinds of communication and characteristics which are key to intercultural effectiveness and demanded in today's world.

Despite the above mentioned reports and study, law schools have not yet addressed intercultural learning in systematic ways nor prioritized its importance in pre-professional legal education. ${ }^{30}$ A 2008 Michigan Bar Journal article pointed out,

22 Id. at 129.

23 Id. at 139

24 See William M. Sullivan ET Al., supra note 9, at 150.

$25 I d$.

26 Id. at 151.

27 Marjorie M. Shultz and Sheldon Zedeck, FinAl Report, Identification, Development, and Validation of Predictors for Successful Lawyering (September 2008), http://www.law.berkeley.edu/files/LSACREPORTfinal-12.pdf [hereinafter Final Report]; see also Marjorie M. Shultz and Sheldon Zedeck, Predicting Lawyer Effectiveness: Broadening the Basis for Law School Admission Decisions, 36 LAW \& Soc. INQUiRY 620 (2011), available at http://www.breakintolaw.files.wordpress.com/ 2012/10/predicting-effectiveness-shultz-zedeck.pdf.

28 Shultz \& Zedeck, supra note 27; Nancy B. Rapoport, Rethinking U.S. Legal Education: No More "Same Old, Same Old," 45 Conn. L. Rev. 1409, 1417 (2013).

29 Shultz \& Zedeck, supra note 27.

30 Beverly I. Moran, Disappearing Act: The Lack of Values Training in Legal Education-A Case for Cultural Competency, 38 S.U. L. Rev. 1 (2010). Professor Moran 
"In truth, good lawyers - culturally sensitive and aware lawyers employ considerable skill. Cultural competencies can be taught. Indeed they are taught to educators, translators, social workers, nurses, missionaries, and a host of others who deal with diverse populations. By and large, they are not taught to lawyers." 31

In short, those involved with legal education reform have been waving their arms frantically for over two decades to call attention to the need for IE education for law students. Despite this urgent call for attention, American legal education entities have not yet systematically addressed the need for development of intercultural knowledge, skills and attitudes in law students. ${ }^{32}$ The present moment is an opportune time for remedying that failure.

\section{The Time Is Ripe for Systemizing Intercultural EFFECTIVENESS (IE) TRAINING}

American-trained lawyers are increasingly called upon to interview, counsel, and represent individuals who may speak a different language and/or may come from a very different experience of life than the lawyer's own. When lawyers help resolve disputes, they negotiate with other lawyers who have differing cultural backgrounds and experiences, or appear before judges, juries, arbitrators, and mediators whose backgrounds and life experiences differ from their own. Lawyers who act as governmental and institutional policymakers need to employ intercultural and multicultural awareness ${ }^{33}$ when creating policies or systems to ensure equal access to justice or opportunity. Reform advocates and those who represent marginalized individuals require familiarity with the dominance of privilege and the challenges of difference in order to be effective. And in our increas-

explores the sharp contrast between medical and legal education with respect to cultural competence and diversity. ("In contrast, although ABA standards 211 and 212 require that law schools demonstrate their commitment to diverse faculties and student bodies, the law school curriculum tends to exclude race, gender, or class from the curriculum. As a result, legal education leaves little space for discussion of gender, race, ethnicity, or class in the law school classroom. Further, the case method, which is generally accepted as the central defining feature of the last one hundred years of legal education, tends to maintain, and even reinforce, class, gender, and race hierarchies. Thus, law students are doubly shielded from important aspects of their lives as professionals and citizens."); see also Andrea A. Curcio, Teresa E. Ward \& Nisha Dogra, A Survey Instrument to Develop, Tailor, and Help Measure Law Student Cultural Diversity Education Learning Outcomes, 38 NovA L. REv. 178 (2014).

31 Nelson P. Miller, Beyond Bias-Cultural Competence As a Lawyer Skill, 87-JuN Mich. B.J. 38 (2008). Professor Miller identified five areas in which lawyers need to demonstrate cultural competence: communication, individual cognition, individual and family resources, cultural references and relationships. $I d$. at 39.

32 Bliss ET AL., supra note 9; Curcio et al., supra note 30.

33 See sources cited supra note 4. 
ingly globalized community, lawyers who work in business are required to demonstrate intercultural skills and cultural awareness in negotiating and working on transactional matters on a daily basis. In all these and many other settings, a lawyer's multicultural knowledge, intercultural communication skills, and cultural sensitivity are often the keys to avoiding misunderstanding and promoting effective problem solving. ${ }^{34}$ Whether a lawyer is representing an immigrant, traveling to another country to negotiate a deal, or simply working with others from backgrounds different from his or her own, the lawyer's ability to effectively identify and navigate difference is of the utmost importance. 35

Today's graduates and "tomorrow's lawyers" 36 must be equipped with knowledge, skills and attitudes to effectively represent clients whose personal and professional matters will extend beyond local, state and national borders and communicate with individuals whose cultural background, identity and experience may be radically different from the lawyers' own. ${ }^{37}$ The demand for interculturally effective lawyers results not only from the diverse identities of clients, the diverse identities of lawyers, and the professional acculturation of lawyers $^{38}$ but also from the rapidity at which globalization has affected the daily life of lawyers and their clients.

In making the point that all lawyers need to be prepared for the globalized reality in which we live and practice, one colleague of mine $^{39}$ uses the real life example of a former student and local lawyer who represents small farmers. This lawyer could not expect, as a lawyer two generations ago might have, to work only on matters involving other local lawyers and businesses. She has been pulled into matters involving international companies and international contracts that deal with seed, transport of seed, and equipment parts. She and other local lawyers will continue to interact with a much more diverse set of individuals with far different backgrounds and experience than their own, just by the nature of being a 21st century lawyer.

\footnotetext{
34 Moran, supra note 30.

35 Id.

36 Richard Susskind, Tomorrow's Lawyers (2013).

37 Curcio et al., supra note 30, at 184; Therese O'Donnell, Anthony O'Donnell \& Richard Johnstone, Developing a Cross-Cultural Law Curriculum 13 (1997); Nelson P. Miller et al., Equality as Talisman: Getting Beyond Bias to Cultural Competence as a Professional Skill, 25 T.M. Cooley L. Rev. 99, 111-13 (2008); Moran, supra note 30, at 24-26.

38 See Bryant, The Five Habits, supra note 13.

39 Thank you to my former Dean, Thomas Guernsey, for this real life anecdote and example.
} 
Similarly, given the trends in immigration, population and business, tomorrow's government, business, and not-for-profit leaders will need to bring intercultural awareness to bear when problem-solving about policies, employees, issues of fairness and expected or agreed upon behavior regardless of whether these leaders work on the local, state, or national level. ${ }^{40}$ Moreover, lawyers will be expected to be sensitive and sensible, not only about others' culture, but about their own implicit cultural biases. Because of the advances in knowledge about how the brain draws conclusions, all lawyers will be expected to be aware of their own implicit bias and to navigate issues of difference and privilege with others or on behalf of others. ${ }^{41}$ They will need to identify methods for preventing or addressing cross-cultural misunderstandings, and will need to have inculcated habits and attitudes which will improve their intercultural learning over the course of their professional life. ${ }^{42}$

Educators in the medical, health and social science fields have already led the way in developing curricula to integrate cross-cultural and IE training into their students' pre-professional education. ${ }^{43} \mathrm{Just}$

40 "If recent trends continue, immigrants will play a leading role in our future economy. Between 1990 and 2005, immigrants started one out of four venture-backed public companies. Large American firms are also increasingly led by people with roots in foreign countries, including 15 of the Fortune 100 CEOs in 2007. . . For all these reasons, the United States of 2050 will look different from that of today: whites will no longer be in the majority. The U.S. minority population, currently 30 percent, is expected to exceed 50 percent before 2050 . No other advanced, populous country will see such diversity. . . . In fact, most of America's net population growth will be among its minorities, as well as in a growing mixed-race population. Latino and Asian populations are expected to nearly triple, and the children of immigrants will become more prominent. Today in the United States, 25 percent of children under age 5 are Hispanic; by 2050, that percentage will be almost 40 percent." Joel Kotkin, The Changing Demographics of America, Smithsonian MAG. (Aug. 2000), http://www.smithsonianmag.com/40th-anniversary/the-changingdemographics-of-america-538284/?noist.

41 Debra Lyn Bassett, Deconstruct and Superstruct: Examining Bias Across The Legal System, 46 U.C. Davis L. Rev. 1563, 1581 (2013).

42 Curcio, et al., supra note 30, at 184 (citing Franklin A. Gevurtz, Report Regarding the 2011 Pacific McGeorge Workshop on Promoting Intercultural Legal Competence (The "Tahoe II" Conference), 26 Pac. McGeorge Global Bus. \& Dev. L.J. 63, 71 (2013); Scharlette Holdman \& Christopher Seeds, Cultural Competency in Capital Mitigation, 36 Hofstra L. Rev. 883, 883-84 (2008); Ascanio Piomelli, Sensibilities for Social Justice Lawyers, 10 Hastings Race \& Poverty L.J. 177, 185-86 (2013), http://papers.ssrn.com/ sol3/papers.cfm?abstract_id=2451300.

43 Curcio et al., supra note 30, at 185. ("Decades ago, health care educators recognized the need for cultural competence education because studies indicated there were significant disparities in health outcomes related to patients' race and ethnicity); Ass'N OF AM. MeD. Colls., Tool for Assessing Cultural Competence Training (TACCT) (2010), available at https://www.aamc.org/download/54344/data/tacct_pdf.pdf [hereinafter Ass'N of Am. Med. Colls, Tool for Assessing Cultural Competence Training (TACCT)]; see also National Consortium for Multicultural Education for Health Professionals (2009), http://culturalmeded.stanford.edu/; Cultural Competence Assessment 
recently, some legal educators have begun to develop measures to try to catch up with the other helping professions. For example, Professor Andi Curcio and her co-authors have developed a survey tool to assess professional students' progress across the spectrum of "cultural sensibilities." 44 The University of Dayton School of Law has identified "inclusivity" as an attitudinal student learning outcome and assesses student participation in activities "designed to improve the justice system and the profession, such as ridding both of bias ..." and student demonstration of "diversity skills, such as sensitivity to social and cultural difference." 45 In a follow up book to Best Practices and the Carnegie Report, IE is identified as an essential knowledge, skill and value "in a changing world." 46 The world has changed and legal education must prepare today's students for our multicultural, globalized world by including IE in its professional development objectives.

\section{The Newly Adopted ABA Outcomes Framework}

The anticipated revision of ABA law school accreditation standards is the second factor making the call to systemize the development of cross-cultural and IE skills in law students so timely. In August of 2014, the ABA House of Delegates is expected to adopt proposed revisions to the standards and rules of procedures for accrediting law schools which would require all law schools to establish, publish and assess learning outcomes for all students. ${ }^{47}$ In particular, law schools must establish and publish learning outcomes designed to prepare students for "effective, ethical and responsible participation as members of the legal profession." 48 Such preparation must include under Standard 302:

Tools, http://www.omh.ny.gov/omhweb/cultural_competence/assessment_tools.html (last modified Apr. 16, 2014).

44 Curcio et al., supra note 30.

45 See University of Dayton School of Law Learning Outcomes \& Criteria (Mar. 2009) (on file with authors) ("Learning Outcome 9: Graduates will adopt the Marianist charism of faith, service, community and inclusivity in their professional and personal life.").

46 BLISs ET AL., supra note 9.

47 For an outline of the proposed adoption see http://www.americanbar.org/groups/ legal_education/committees/standards_review.html; see the memo from the chair of the Council on Legal Education. Memorandum from Hon. Solomon Oliver, Jr. to the Council of the Section of Legal Education and Admissions to the Bar (May 14, 2014), http:// www.americanbar.org/content/dam/aba/administrative/legal_education_and_admissions _to_the_bar/council_reports_and_resolutions/June2014_june_oliver_memo_to_council_re_ standards.authcheckdam.pdf.

48 See Revised Standards for Approval of Law Schools, Am. Bar Ass'n 14 (Aug. 2014), http://www.americanbar.org/content/dam/aba/administrative/legal_education_ and_admissions_to_the_bar/council_reports_and_resolutions/201406_revised_standards_ clean_copy.authcheckdam.pdf [hereinafter Revised Standards]. 
(a) Knowledge and understanding of substantive and procedural law;

(b) Legal analysis and reasoning, legal research, problem-solving, and written and oral communication in the legal context;

(c) Exercise of proper professional and ethical responsibilities to clients and the legal system; and

(d) Other professional skills needed for competent and ethical participation as a member of the legal profession. ${ }^{49}$

Under Interpretation 302-1, "other professional skills needed for competent and ethical participation" in the profession may include "cultural competency."50 Professor Curcio points out that in contrast to medical school accreditors:

Law school accreditors have thus far declined to include cultural competence as one of the mandatory outcomes, in contrast to the accrediting bodies for medical and other professional schools. Instead, the proposed accreditation standard allows individual law schools to decide whether cultural competence should be amongst the school's designated learning outcomes (emphasis added). ${ }^{51}$

Indeed, as Professor Curcio notes, the final proposed regulations do not mandate that all law schools identify IE as a required student learning outcome (SLO). However, the comments and discussion surrounding the identification of skills needed for competent and ethical participation in the legal profession demonstrate why most schools should identify IE as an essential SLO. For example, the Society for American Law Teachers argued:

Today's effective lawyers must have the ability to work in a collaborative environment, to communicate effectively with people from diverse backgrounds, and to be self-reflective in their work to enable them to engage in the life-long learning process of the effective lawyer. ${ }^{52}$

\footnotetext{
49 Id.

$50 \mathrm{Id}$.

51 See Curcio et al., supra note 29, at p3n7 (citing Liaison Comm. on Med Educ., Functions and Structure of a Medical School; Standards for Accreditation of Medical Education Programs Leading to the M.D. Degree 10 (2012)) available at http://www.lcme.org/publications/functions2012may.pdf (requiring medical schools to document objectives relating to the development of skills in cultural competence); see also The Nat'l Architectural Accrediting Bd., Inc., 2009 Conditions for ACCREDitAtion 22 (2009), available at http://www.naab.org/accreditation/2009_conditions (listing cultural diversity as one of its student performance criteria).

52 Letter from the Society of American Law Teachers (SALT) to Jeffrey E. Lewis, chair, ABA Standards Review Committee 2 (Apr. 13, 2012), http://www.americanbar. org/content/dam/aba/migrated/2011_build/legal_education/committees/standards_review_ documents/outcome_measurements/20120416_comment_outcome_measures_salt.auth checkdam.pdf; see also Mary A. Lynch, An Evaluation of Ten Concerns about Using
} 
Law schools can and should use the opportunity created by the new mandated outcomes framework to focus on the attitudes, values and skills of intercultural effectiveness. As Deans, Associate Deans, Curriculum and Assessment leaders, and faculty committees engage in the process of identifying SLO's, they should prioritize IE education as necessary preparation for law graduates "effective, ethical, and responsible participation as members of the legal profession" 53 under standard 301. In addition, under Standard 302, developing IE knowledge, skills and values should be found necessary for exercising "proper professional and ethical responsibilities to clients and the legal system" 54 as well as for ensuring law graduates" "competent and ethical participation as a member of the legal profession." 55

\section{Changing LANDSCAPE FOr Legal EMPloyment FOR LAW GRADUATES}

The recent decline in the demand for traditional legal services is now being labeled a permanent restructuring of the market and constitutes the third trigger for systemizing intercultural effectiveness learning in law schools. ${ }^{56}$ The arguments Richard Susskind made in his 2010 publication The End of Lawyers?: Rethinking the Nature of Legal Services were greeted with mixed reactions of acceptance and rejection by legal commentators. ${ }^{57}$ By the time he published Tomorrow's Lawyers in 2013,58 most lawyers, legal educators and legal observers acknowledged that the landscape for legal employment had radically changed. According to Susskind, law will become a "world of virtual courts, Internet-based global legal businesses, online document production, commoditized service, legal process outsourcing, and web-based simulated practice."59 Professor William Henderson who closely follows this new world of law sees opportuni-

Outcomes in Legal Education, 38 WM. Mitchell L. Rev. 976, 1004 (2012) ("Identifying institutional or course outcomes should move beyond identification of knowledge components to embrace objectives, which include skills, such as cultural competence, and values, such as diverse perspectives.”).

53 Revised Standards, supra note 48.

54 Id.

$55 I d$.

56 Michael Bonasso \& William E. Vrla, A Profession On The Verge Of A Paradigm Shift?, Metro. Corp. Counsel 39 (Dec. 2013), http://www.metrocorpcounsel.com/pdf/ 2013/December/39.pdf; William D. Henderson, From Big Law to Lean Law, 38 InT'L Rev. L. \& ECON. 5 (2014); Susskind, supra note 36.

57 See, e.g., Paul F. Kirgis, The Knowledge Guild: The Legal Profession in an Age of Technological Change, 11 Nev. L. J. 184 (2010) (reviewing Susskind's book).

58 SussKind, supra note 36.

59 Id. 
ties in this paradigm shift for developing adaptable and prepared law graduate:

The types of education that will attain the highest valuation are complex problem-solving skills that enable law school graduates to communicate and collaborate in a highly complex, globalized environment. This is not vocational training; it is the creation of a new model of professional education that better prepares our graduates for the daunting political and economic challenges ahead.... What I am advocating is the creation of a competency-based curriculum. In a competency-based curriculum, we identify the knowledge, skills, behaviors, and attributes of highly successful professionalslawyers and nonlawyers - and then work backwards. ${ }^{60}$

Professor Henderson's focus on a competency-based curriculum and the attributes of "highly successful professionals" 61 integrates nicely with the Shultz and Zedeck's study of Lawyering Effectiveness, referenced earlier. ${ }^{62}$ Notably, as we prepare lawyers to be highly effective, the Shultz and Zedeck study demonstrates that many effectiveness factors involve communication, self- awareness and behavioral capacities - the kind of skills and values emphasized by IE. ${ }^{63}$

Out of the 26 factors identified by Shultz and Zedeck as characteristics of successful lawyers, at least nine involve the kind of skills and values important to development of intercultural effectiveness:

Creativity/Innovation: Thinks "outside the box," develops innovative approaches and solutions.

Problem Solving: Effectively identifies problems and derives appropriate solutions.

Practical Judgment: Determines effective and realistic approaches to problems.

Providing Advice \& Counsel \& Building Relationships with Clients: Able to develop relationships with clients that address client's needs.

Speaking: Orally communicates issues in an articulate manner consistent with issue and audience being addressed.

Listening: Accurately perceives what is being said both directly and subtly.

Questioning \& Interviewing: Obtains needed information from others to pursue issue/case.

Self-Development: Attends to and initiates self development.

\footnotetext{
60 William D. Henderson, A Blueprint for Change, 40 PEPP. L. REv. 461, 493 (2013).

61 Id.

62 Shultz \& Zedeck, supra note 27.

$63 \mathrm{Id}$.
} 
Able to See the World Through the Eyes of Others: Understands positions, views, objectives, and goals of others. ${ }^{64}$

The skills and values identified by Shultz and Zedeck, and indirectly called for by Henderson and Susskind, are transferable beyond traditional legal employment and have been embraced by other professionals with whom lawyers will be working. These intercultural and cross-cultural skills and values will be important for students to showcase when reaching for opportunities created by the new globalized, digitalized world.

In sum, the confluence of the three factors discussed above - the demand for interculturally effective professionals in today's interconnected and globalized world, the newly adopted ABA requirements, and the restructuring of the legal employment landscape - creates the impetus for action by law schools in identifying, teaching and assessing intercultural effectiveness outcomes.

\title{
Experiential Learning in Clinical Courses and INTERCULTURAL EFFECTIVENESS
}

\begin{abstract}
Law schools should teach cross-cultural lawyering and theory both in the classroom as a doctrinal subject and in experiential and clinical courses in which live or simulated client representation is closely supervised and modeled. Introducing the topic early in the law school curriculum and reiterating its value throughout the program is essential to convey the message that effective lawyering requires close attention to cultural norms and attitudes. 65
\end{abstract}

Intercultural effectiveness and cross-cultural lawyering can be taught in many settings: in orientation of students to law school, by using hypotheticals and problems in doctrinal courses which provide opportunity for students to reflect on intercultural communication, by assigning readings and small group work in seminars, through simulations where students face intercultural challenges, in field placement opportunities where reflection on cross-cultural interactions is required, ${ }^{66}$ and in live client clinical courses through rounds, during supervision, in one-to-one meetings, and through reflection journals.

\footnotetext{
64 Shultz \& Zedeck, supra note 27; FinAL REPORT, supra note 27.

65 Tamar R. Birckhead, Culture Clash: The Challenge of Lawyering Across Difference in Juvenile Court, 62 Rutgers L. Rev. 959, 988 (2010).

66 Externships provide an opportunity for law students to practice law in a legal setting under the supervision of a licensed and experienced attorney. . . Students are required to write journals reflecting about their experiences and skill development. Faculty supervisors reviewing those journals help students identify and explore journal entries in which there are underlying issues of culture, for example, when students reveal unintentional biases potentially impacting advocacy. Cynthia M. Ward \& Nelson P. Miller, The Role of Law Schools in Shaping Culturally Competent Lawyers 89-JAN, МicH. B.J. 16, 18 (2010).
} 
Indeed, many commentators have argued that cross-cultural communication and intercultural skill building and value development should be mainstreamed throughout the curriculum. ${ }^{67} \mathrm{I}$ do not disagree with such aspirations; teaching about cross-cultural lawyering and intercultural effectiveness throughout the curriculum is ideal.

I argue here, however, that experience based learning opportunities create uniquely ideal settings for this kind of learning. As I discussed in my 2012 article on learning outcomes:

For many years, clinical professors have consistently emphasized the role cultural competence plays in preparing students to assume the role of lawyer. In reality, practicing with cultural competence is a fundamental lawyering skill, as is the ability to critically evaluate laws, culture, and societal systems from a variety of perspectives or lenses. Respect for difference and other cultures and beliefs is also a fundamental lawyer value. ${ }^{68}$

In fact, much of the early law review literature on cross-cultural lawyering was written by clinical professors. ${ }^{69}$ As far back as 1997, Professor Michelle S. Jacobs transformed clinical teaching of clientcentered counseling when she pointed out:

I address my suggestions for changes to the manner in which clientcentered counseling training can be supplemented. I propose that in conjunction with client-centered counseling, we engage in cross-cultural lawyer and student self-awareness training (CCLASS). I propose that all students, particularly those who will be working with either indigent or culturally dissimilar people, be taught how to interact with clients who differ from them. Before students counsel any indigent client, the students should have some self awareness and understanding of their value system. Without that awareness, students will not be able to recognize the interpretive violence they can do. I do not believe we can assume that lawyers will be able to either seize a limited autonomy or extract partial understandings unless they are trained to do so (footnotes omitted). ${ }^{70}$

Almost a decade later, Ascanio Piomelli noted "since Jacobs" article, many clinicians have written thoughtfully about how students and

67 See Curcio, supra note 30 (Numerous legal educators have argued that cultural sensibility skills should be infused throughout the curriculum.) See AnTHOny O'Donnell \& Richard Johnstone, Developing a Cross-Cultural Law Curriculum 13 (1997); Nelson P. Miller et al., Equality as Talisman: Getting Beyond Bias to Cultural Competence as a Professional Skill, 25 T.M. Cooley L. Rev. 99, 111-13 (2008); Moran, supra note 30, at 24-26.

68 Lynch, supra note 52, at 1004-05.

69 Some examples include Professors Jane Harris Aiken, Sue Bryant, Christina Zuni Cruz, Michelle Jacobs, Jean Koh Peters, and Carwina Weng.

70 Michelle S. Jacobs, People From the Footnotes: The Missing Element in Clientcentered Counseling, 27 Golden Gate U. L. Rev. 345, 405-06 (1997). 
attorneys might best prepare to work effectively with clients across dimensions of cultural difference - such as race, ethnicity, nationality, class, gender, sexual orientation, etc."71

In addition, the "original religious text" on teaching and learning about cross-cultural lawyering- "The Five Habits" for developing competence in cross-cultural lawyering-was written by two clinical professors.$^{72}$ While the current leading text on professional development of clinical teachers opines:

If lawyers, and thus clinical teachers, are not aware of how human traits and institutional character influence the pursuit of the client's claims and interests, their expertise in the mechanics of legal skills may be insufficient to maximize their client's interests.... Most law students, and perhaps most clients, are not particularly cross-culturally competent, and most of us make assumptions about unfamiliar cultures. ... These schemas are further complicated by economic, educational, racial, and cultural differences.

... [L]awyers, especially those representing poor clients, clients of a different race or culture, or clients whose life experiences are unlike the lawyer's must develop cultural competence, learn to question their assumptions, and be able to separate moral and value dilemmas from ethical rules in order to serve their clients while acting in accordance with the rules of our profession.

The nature of a case or project and the values or morals of a client or team member sometimes force students to confront, and perhaps alter, their own beliefs and their own world views. They must do so

71 Ascanio Piomelli, Cross-Cultural Lawyering by the Book: The Latest Clinical Texts and A Sketch of A Future Agenda, 4 Hastings Race \& Poverty L. J. 131, 132 (2006) (citing Jane Harris Aiken, Striving to Teach Justice, Fairness and Morality, 4 Clinical L. REv. 1 (1997)) (characterizing recognition of power and privilege as central to doing justice); The Five Habits, supra note 13 (describing approach developed with Jean Koh Peters); Christine Zuni Cruz, [On the] Road Back In: Community Lawyering in Indigenous Communities, 5 Clinical L. Rev. 557 (1999); Marjorie A. Silver, Emotional Competence, Multicultural Lawyering and Race, 3 FL. Coastal L.J. 219 (2002); Paul R. Tremblay, Interviewing and Counseling Across Cultures: Heuristics and Biases, 9 Clinical L. Rev. 373 (2002) (proposing use of heuristics, i.e., tentative generalizations, concerning areas in which standard client-centered model may not fit clients from diverse cultures, while also urging lawyers to develop self-awareness of their own cultural backgrounds and biases); Carwina Weng, Multicultural Lawyering: Teaching Psychology to Develop Cultural SelfAwareness, 11 Clinical L. Rev. 369 (2005). See also Leslie G. Espinoza, Legal Narratives, Therapeutic Narratives: The Invisibility and Omnipresence of Race and Gender, 95 MicH. L. REv. 901 (1997) (advocating a race-sensitive, rather than a colorblind, approach to lawyering, with appropriate training to practice it); Russell G. Pearce, White Lawyering: Rethinking Race, Lawyer Identity, and Rule of Law, 73 Fordham L. Rev. 2081 (2005).

72 The Five Habits, supra note 13; Susan Bryant \& Jean-Koh Peters, Five Habits for Cross-Cultural Lawyering, in Race, Culture, Psychology \& Law (Kimberly Holt Barrett \& William George, eds. 2005). 
while remaining true to themselves, in good standing with their profession, and loyal to their clients. ${ }^{73}$

This close relationship between the clinical community and cross-cultural teaching also extends to work overseas. Clinical teachers have also been highly active in intercultural work abroad as "the trend toward globalization and the creation of a more integrated world has manifested itself in the legal education community: the increased number of visits by U.S. lawyers and law professors to overseas law schools." "74 Clinicians have been involved "both in broad based projects in Iraq, China, and Russia as well as smaller scale ones in other parts of the world, particularly sub-Saharan Africa." 75

The very nature of clinical course design and teaching provides fertile ground for cross-cultural and intercultural student learning. The non-privileged demographics of most clinic clientele offer an ideal context for exploration of cross-cultural issues ${ }^{76}$ while the desire to do justice by one's client, the focus on the real instead of the hypothetical, and the donning of the role of lawyer are motivating ${ }^{77}$ factors for students to improve communication and rapport by all means possible. ${ }^{78}$ As Professor Andi Curcio writes in a recent piece, "Many

73 Wallace J. Mlyniec, Where To Begin? Training New Teachers in the Art of Clinical Pedagogy, 18 Clinical L. Rev. 505, 542 (2012).

74 Peggy Maisel, The Role of U.S. Law Faculty in Developing Countries: Striving for Effective Cross-Cultural Collaboration, 14 Clinical L. Rev. 465, 465 (2008)

$75 \mathrm{Id}$.

76 "In-house legal clinics often provide students with intercultural practical legal experiences through individual client representation. Students serve diverse populations in clinics for disability law, low-income taxpayers, urban redevelopment, human trafficking, and elder law. Clinics also expose students to other intercultural experiences. Many clinics have a community outreach and education component where students give presentations to community groups. At the Sixty Plus Elderlaw Clinic at Cooley's Lansing campus, the clinic director discerned that certain minority communities underutilized the clinic even though there remained a need for legal services. In an effort to address the issue, the director organized several focus groups in the minority communities attended." Ward \& Miller, The Role of Law Schools in Shaping Culturally Competent Lawyers, supra note 66 at 18.

77 See Kenneth R. Kreiling, Clinical Education and Lawyer Competency: The Process of Learning to Learn from Experience Through Properly Structured Clinical Supervision, 40 MD. L. Rev. 284, 287 (1981) ("The assumption of a professional role by the students can generate strong motivation to learn and to perform effectively"); Jane H. Aiken, et al., The Learning Contract in Legal Education, 44 MD. L. REv. 1047, 1053-54 (1985) (clinical courses "empower [students] by pressing them to accept real responsibility, both for case management and for the nature of their educational experiences in the clinic.").

78 For example, "In an increasingly globalized and multicultural world, now more than ever, leading legal education centers are obliged to develop culturally sensitive leaders, able to transcend political boundaries and address issues of social injustice both domestically and abroad. Since the development of the first international human rights clinic thirty years ago, clinicians have looked to human rights clinics, and particularly international fieldwork, as a way to advance clinical pedagogy and cross-cultural training. Practitioners and clinicians have recognized the capacity of international human rights 
have written lengthy and thoughtful articles about the causes of student resistance to multicultural learning, and potential remedies thereto ... to the extent students understand how biases effect one's ability to represent clients and succeed in the workplace, they may be more open to exploring those biases."79 Most students recognize that in clinical courses they are beginning to form professional identity and embrace professional values not simply learn "the law." Thus, they are less likely to reject cross-cultural lawyering development as "tangential" or unnecessary to their learning.

Clinical courses are well suited for developing habits in students which are central to improving cross-cultural communication because of the intense focus in clinic on formative assessment and feedback. The hallmark of clinical teaching is the cycle of setting goals, acting, and reflecting on that action, while the intimate nature of the professor-student relationship in clinic allows for continuous assessment and reflection on self-assessment. ${ }^{80}$ This process is particularly important for developing cross-cultural skills in self-awareness ${ }^{81}$ and appreciation of one's own implicit biases. ${ }^{82}$ Moreover, the one-to-one nature of clinical supervision also allows inhouse clinical professors to immerse students more deeply in the "causes of the disparities and make the connection to ongoing racism explicit."83 For field placement students, the guided and structured reflection opportunities which faculty provide ensure that the rich examples of cross-cultural tension, privilege, bias, preference, and injustice which populate our

fieldwork to prepare students to negotiate cultural challenges, providing a framework for interaction between students, clients, partners, and other stakeholders in the field. Kathleen Kelly Janus \& Dee Smythe, Navigating Culture in the Field: Cultural Competency Training Lessons from the International Human Rights Clinic, 56 N.Y.L. ScH. L. Rev. 445, 446 (2012).

79 Andrea A. Curcio, Social Cognition Theory and the Development of Culturally Sensible Lawyers, __ Nev. L. Rev. (forthcoming, 2014).

80 See generally Victor M. Goode, There Is a Method(ology) to this Madness: A Review and Analysis of Feedback in the Clinical Process, 53 OKLA. L. Rev. 223 (2000) (describing in detail the importance and depth of the clinical feedback process.).

81 See The Five Habits, supra note 13.

82 This requires vigilant attention to "one's own cultural perspectives and their impact on attitudes, communication patterns, interactional habits, and cultural assumptions." Ascanio Piomelli, Cross-Cultural Lawyering by the Book: The Latest Clinical Texts and A Sketch of A Future Agenda, 4 Hastings Race \& Poverty L. J. 131, 157 (2006) (quoting Robert F. Cochran, Jr., John M.A. DiPippa \& Martha M. Peters, The Counselorat-Law: A Collaborative Approach to Client Interviewing and Counseling (2d ed. 2006)).

83 Deborah N. Archer, There Is No Santa Claus: The Challenge of Teaching the Next Generation of Civil Rights Lawyers in A "Post-Racial” Society, 4 Colum. J. RACE \& L. 55, 71 (2013). 
legal systems do not pass unnoticed by the clinical student. ${ }^{84}$ And unlike "hypotheticals" which can be attacked as "unrealistic" or "dated," the fresh real life examples from the students own placement provide a more motivating context for reflection and learning.

In conclusion, the longtime focus of clinical teachers on development of cross-cultural lawyering skills, combined with the motivating engagement with real clients and with real life lawyering, and the opportunity for continual formative assessment make clinical courses uniquely suited to the teaching and learning of intercultural effectiveness and cross-cultural lawyering. As law schools prepare to articulate and assess their identified student learning outcomes, they must include intercultural effectiveness as an essential outcome. As law schools seek to create highly skilled and employable graduates who can succeed in today's globalized world, they should focus attention and resources on the teaching and learning of intercultural effectiveness in clinical experiential opportunities. Identifying intercultural learning outcomes and acknowledging the role of clinical courses in developing cross-cultural lawyering skills will maximize the likelihood that students will not only learn, but learn well.

84 See J.P. Ogilvy et al., Learning from Practice: A Professional Development Text for Legal Externs (2d ed. 2007); Nancy M. Maurer \& Liz Ryan Cole, Design, Teach and Manage: Ensuring Educational Integrity in Field Placement Courses, 19 Clinical L. Rev. 115, 144 (2012) (listing goals for field placement courses "Interpersonal and Professional Skills-including collaboration, civility, and cultural competence.)." 